\title{
Hegemonik Yaklaşımların Eleştirisi ve Güç Yorumu
}

\author{
Elif GÜRDAL ${ }^{1}$
}

Özet: Uluslararası ilişkiler literatüründe hegemonya kavramı, Soğuk Savaştan sonra farklı yaklaşımlar üzerinden istikrar ve dünya düzeni açısından incelenmiştir. Ancak bu analizler içerisinde farklı araçlar öncelikli olmuş ve düzen ile güç anlayışı her bir kurama göre farklı açılardan değerlendirilmiştir. Hegemonya kavramını doğrudan analiz eden dört hegemonya görüşü vardır. Bu çalışmada, her bir görüşün mevcut uluslararası ilişkiler yapısının hegemonya anlayışııı analiz etmede ne derecede yeterli olduğu ve aldıkları eleştirilerin hangi açılardan geldiği değerlendirilmeye çalıșılmıştır. Karşılaştırmalı bir kavramsal çalışma olarak, uluslararası sistemin tek bir kuram üzerinden yorumlanamamasındaki zorlukların sebeplerini irdelemek amaçlanmıştır.

Anahtar Kelimeler: Hegemonya, güç, eleştirel bakış, karşılaştırmalı analiz.

\section{Criticism of Hegemonic Approaches and Power Interpretation}

Abstract: In the international relations literature, the concept of hegemony is examined in terms of stability and world order through different approaches after the cold war. However, among these analyzes, different tools were prioritized, and the understanding of order and power was evaluated from different perspectives according to each theory. There are four views of hegemony that directly analyze the concept. In this study, it has been tried to evaluate how sufficient each concept is in analyzing the understanding of hegemony in the current international relations structure and from which aspects the criticisms they receive. As a comparative conceptual study, it aimed to find the reasons for the difficulties in interpreting the international system from a single theory.

Keywords: Hegemony, power, critical view, comparative analysis.

\section{Summary}

Conceptual analyzes that stand out due to the need for power and order during the cold war have been tried to be interpreted over hegemony. This study focuses on the way the concept of hegemony is handled since its introduction to the literature and its deficiencies in interpreting the system. As a comparative literature study, hegemonic views have examined the competencies in defining the international system. Whether the four hegemony approaches alone can interpret the international understanding of power has created a controversial area. These four views are the critical neo-gramic approach, the hegemonic stability approach, the liberal institutionalist approach, and the world-systematic approach, which deal with the concept of hegemony through critical, realist / neorealist, liberal / neoliberal and world-system approaches, respectively. The only point where these four views meet is the understanding of order and the desire for power interpretation. In other words, four approaches are working on what power and order are.

The perspectives of the four approaches to order and power are different. In this respect, the tools they defend are diversified. The phenomenon of power also has a different meaning according to each theory. In this regard, critical perspectives towards each other constitute the main conceptual discussion environment. Each view claims that the process leading to the order and the means of emerging hegemony differ.

According to the critical approach, power is the capacity to convince a class community with intellectual morality. Ideas and the classes to be gathered around these ideas should be convinced by their own will. It will

\footnotetext{
${ }^{1}$ Orcid ID: https://orcid.org/0000-0001-5110-6524, Dr., Süleyman Demirel Üniversitesi Sosyal Bilimler Enstitüsü, Uluslararası İlişkiler Anabilim Dalı, Avrupa Birliği Çalışmaları, Isparta-Türkiye, elfgurdal@gmail.com.
} 
also provide a hegemony order that will ensure this. On the other hand, the second approach, the view of henemonic stability, defines hegemony as the power that can transform this military and economic ability of the actor with material capacities into political domination. For Hegemon the actor, the ability to coordinate the security-based economic functioning are outstanding features. If hegemony is absent, there is no stability. According to the third approach, liberal institutionalists, hegemony is the pioneer who can establish cooperation, organization and institutional mechanisms. Actors, who have structural rules like international organizations and are called regimes, are convinced and participated in this interconnected structure. This ability to persuade, economic coordinating ability, and political power are essential for hegemony. The system will continue to function even if hegemony goes to decline in strength after building this order. Finally, the world-systems approach sees international relations as cycles of power ups and downs. Economic and military capacities in the classical sense are important power sources. However, hegemonically, the subject of study is the cycles. This system has been fluctuating since the accumulation of capital.

One approach is insufficient to define hegemony in terms of international order. For example, while the critical neo-gramsian hegemony approach examines the effect on the form of production and social classes, it puts the influence of spiritual elements such as culture or religion on the power struggle in international relations. However, international crises or collaborations that are shaped on ethnic and religious foundations affect international relations and are a factor in hegemonic struggle.

The emphasis of the approach to hegemonic stability on the material power capacity does not comply with the perspective that the participation of international actors with their own will has a more permanent effect. Today, the situation of foreign public opinion, such as soft power and public diplomacy, appealing to their minds and hearts is criticized in this perspective. However, the feature of the digital age that transformed communication into interaction increased the individual participation rates in politics; human rights discourses, democracy debates or increased the voices of individuals. Since this process gives birth to a global public that needs to be persuaded, the ability to provide consent is prominent.

The liberal institutionalist approach pushes the existence of hegemony into the background after cooperation and the establishment of the institutional mechanism. However, as the absence of a leading actor in the international system, namely hegemony, will generate rival hegemones, the hegemonic process will continue cyclically. In this respect, it can be predicted that a non-hegemonic international relations structure cannot provide stability. Moreover, the argument that participation in the system is proportional to absolute earnings, as liberal institutionalists advocate, is criticized by actors like the EU. The fact that the EU has a greater economic contribution over the Balkans than the USA, for example, is one of the points where this argument is criticized.

While the understanding of hegemony of the world systems approach is through cycles, it is a matter of criticism to push cultural values into the background, which have an impact on the understanding of competition of these cycles. Considering cultural values as local elements and addressing social sciences as a single area, this criticism of this approach is particularly concerned with the definition of cultural diplomacy and public aspirations.

In conclusion, all these critically show that the tools that are effective in understanding hegemony in international relations cannot be defined by a single approach. A single hegemony approach fails to offer a stable order of international relations. Another theory complements the shortcomings of each hegemonic approach.

Keywords: Hegemony, power, critical view, comparative analysis. 


\section{Giriş}

Uluslararası ilişkilerde kavramsal analizler güç ve düzen (istikrar) arayışına yönelik olmaktadır. Tüm uluslararası aktörler kendi çıkarlarını maksimum seviyeye çıkarmaya meyilli olduğundan ortaya çıkan çatışma durumunu ve dengeyi yorumlamak için farklı yaklaşımların ortaya çıktığı görülmüştür. Gücünü arttırma eğiliminde olan devletler hegemon olabilmek için rekabete girmektedirler. Bu açıdan "Hegemonya” kavramı güç bakımından uluslararası sistemin öncüsüne yüklenen atıftır.

Günümüze kadar hiçbir devlet veya güç dünya hakimiyetine tam anlamıyla sahip olamamıştır. Dolayısıyla anarşik yapı içerisindeki güç dağılımı ve dönüşümü uluslararası ilişkiler alanının analiz konuları olmaktadır. Ulus-devletlerin, kurumların veya diğer uluslararası etki yaratabilen aktörlerin baskın yapıları durum analizleri ile değerlendirilmelidir. Zira, üstünlük mücadelesi şekilleri dönemsel olarak farklı isimlendirmeler ile kullanılmıştır. Tek bir gücün otoritesi ve diğer aktörlere etkisi zamanla farklılaşarak dönemin koşullarına uyum sağlamaktadır. İmparatorluk, başat güç, emperyalist güç, süper güç veya hegemon güç bu farklılaşmış hakimiyet anlayışının tanımlama şekillerindendir. $\mathrm{Bu}$ bakımdan hegemonya kavramı Soğuk Savaş sonrası dönemin uluslararası ilişkiler yapısına meşrulaşmış bir şekilde yerleşen isimlendirmedir.

Hegemonya kavramının Türk Dil Kurumu’a göre tanımı "bir devletin başka bir devlet üzerindeki siyasal üstünlüğü ve baskısı" dır (TDK, 2020). Bu da kullanımın genellikle uluslararası ilişkilere mal edilmiş olduğunu göstermektedir. Zaten, kavramsal olarak hegemonya kelimesinin kullanımı uluslararası ilişkiler alanının bir bilim dalı olarak değerlendirilmesi ile aynı süreç içerisinde ortaya çıktığ 1 görülmektedir.

Hegemonya kavramı köken itibari ile Yunan şehir devletlerinin çevre bölgeler üzerindeki hâkimiyeti ve diğer rakip şehir devletleri ile içerisinde olduğu üstünlük mücadelesini tanımlamaktadır (Lentner, 2006:90; Rhodes, 2019: 31). Tek yönetim merkezinin olmadı̆̆ı bu yapıda bir aktörün gücünü arttırma ve diğerine üstünlük kurma eğilimi doğal bir süreç haline gelmektedir. Böylesi bir ortamda ortaya çıkan savaşlar liderlik savaşları haline dönüşmektedir. Bu liderlik algısı da hegemonya kavramının ortaya çıkmasına sebep olmuştur. Diğer yandan, Yunan şehir devletleri döneminde liderlik savaşlarının süregelen bir hale dönüşmesi ve üstünlüğün bir taraf için sağlanamaması süreci, uluslararası ilişkilerin temeli olan diplomasinin de gelişmesine olanak vermiştir (Potyemkin, 2002:36). Bu bakımdan, hegemonyanın sadece savaş yoluyla değil de stratejik bir süreç sonunda belirli koşulların sağlanması şartıyla oluştuğu görülecektir.

Hegemonya kavramı akademik bir çalışma olarak iki dünya savaşı arası dönemde ilk kez İtalyan Komünist parti lideri Antonio Gramsci tarafından kullanılmıştır. Onun hegemonyayı ele alış biçimi toplumsal sınıflar üzerinden olmuştur. Bu kullanım, yönetici bir sınıfın toplumun kalan kesimine hâkim olup; yönlendirebilmesine ve alternatif bir hegemon devlete dönüşmesine dayanmaktadır. Gramsci, bu dayanağı proletarya- burjuva ilişkisinden ele almaktadır (Gramsci, 1989:73). Daha sonra 
kavram, neorealist, neoliberal görüşler çerçevesinde ve ardından özellikle Robert Cox tarafından 1980'li yıllarda eleştirel açıdan ve son olarak da hegemonik sistemin yapısal incelemesi bakımından uluslararası ilişkiler literatürüne kazandırılmıştır. $\mathrm{Bu}$ bağlamda ortaya çıkan dört hegemonya yaklaşımı realist/neorealist, liberal/neoliberal, eleştirel ve sistem analizci yaklaşımı içine alan bir içerikten oluşmaktadır. Bu farklı dört görüş; Hegemonik İstikrar Teorisi, Liberal Kurumsalcı Yaklaşım, Eleştirel Yaklaşım (Neogramsci bakış) ve Dünya Sistemleri Yaklaşımıdır.

Uluslararası ilişkilerde hegemonya konulu kavramsal çalışmalar, çoğunlukla üstünlüğün nasıl sağlandığı ve sürdürüldüğü üzerinedir. Hegemonya alanı içerisindeki aktörlerin ikna edilmesinin şekli ve rıza sağlanarak meşru bir alan oluşturma sürecinin nasıl oluştuğu, teorik inceleme çerçevesini oluşturmaktadır. Dolayısıyla hegemonya yaklaşımları savunucuları kendi savlarına göre gücün ne olduğu, nasıl elde edildiği ve nasıl sürdürülmesi gerektiği ile ilgilenmişlerdir. Hegemonik yaklaşımların istikrar anlayışı ise uluslararası aktörlerin bu gücü elde etmiş öncüye ortaya çıkan sistem içerisinde uyum sağlaması olarak tanımlanabilir.

Her bir teorik yaklaşım hegemonya kavramını savunduğu ana teorik felsefesine uygun olarak ele alırken, bunun bir akademik çatışma haline geldiği görülmektedir. Zira, hegemonya kavramı farklı teorik yaklaşımları olan bir yaklaşım değil, dönemsel olarak yöntemleri değişse de tek başına gücü ve tahakkümü içine alan hakimiyet görüşüdür. Bu bakımdan çalışmada ele alınacak olan farklı hegemonya görüşlerini ana teorik yaklaşımların hegemonya kavramını yorumlama biçimleri olarak alg1lamak gerekmektedir.

Hegemonyaya dair akademik çalışmaların çeşitliliği, genellikle durum değerlendirmelerine yöneliktir. Ancak bu çalışmadaki hedef, bu hegemonya görüşlerinin istikrar odaklı birbiri ile tutarlılığının tespitine ve eleştirel açıklarının neler olduğuna dairdir. Bu açıdan genel hipotez, hegemonya kavramının teorik bir görüş olmaması, farklı teorik hegemonya yaklaşımlarının uluslararası sistemdeki hegemonik durumu tanımlamada yeterli olmadığı ve uluslararası ilişkilerin hegemonik yapısının tek bir kuram üzerinden değerlendirilemeyecek kadar karmaşık olduğudur.

$\mathrm{Bu}$ çalışma, ortaya çıkan hegemonya yaklaşımlarının ana savlarının ve önerilerinin ne derece uygulanabilir olduğunu tespit etmeye yönelik bir değerlendirmedir. Bununla birlikte bu farklı hegemonya yaklaşımlarının her birinin tek başlarına hegemonya ve uluslararası düzen tanımlamasında yeterli olabilir mi sorusuna ulaşmaya çalışılmıştır. Çalışma hegemonya kavramının teorik bakış açılarını karşılaştırmalı olarak ele almıştır. Hegemonya yaklaşımlarının eksiklikleri ve aldıkları eleştirileri irdelenmiştir. Ardından bu yaklaşımların ortak yönleri ve güç olgusuna bakış açıları değerlendirilmiştir. Yöntemi ise, literatür taraması, karşılaştırmalı analizdir ve böylelikle genel bir kavramsal hegemonya değerlendirmesi nitel olarak ele alınmıştır. 


\section{HEGEMONYA YAKLAŞIMLARINDA FARKLILIKLAR}

\section{a. Hegemonik İstikrar Yaklaşımı}

Realist/neorealist açıdan bakıldığında hegemonya kavramında maddi unsurlar öne çıkmakta, diğer yandan rıza sağlama ve ikna etmeye dayalı onay alma faktörü geri planda kalmaktadır. Neorealist yaklaşımlara neoliberal ekonomiyi de dâhil ederek ele alan hegemonik istikrar görüş analizi, ilk olarak Charles Kindleberger'1n The World in Depression 1929-1939 (1973) eserinde ortaya atılmıştır. Kindleberger, dünya piyasasının bir lider tarafından yönetilmesi gerektiğini ve böylelikle bir istikrarın oluşacağını savunmaktadır. Kindleberger, 1929 Ekonomik Buhranın bu kadar etkili olmasındaki sebebi, o dönemde güçlü bir liderin yani hegemonun olmamasından kaynaklandığını öne sürmektedir. Çünkü, söz konusu dönemde İngiliz gücü zayıflamış, ABD ise tam anlamıyla hegemon vasıfta olmaya hazır değil ve de isteksiz kalmıştır.

Hegemon vasıfta olabilmek bir takım koşulları sağlayabilmeyi gerektirmektedir. Bunlar arasında; uluslararası pazarın istikrarını sağlayabilecek, koordine edici bir kontrol mekanizmasına sahip olmak vardır. Bu yüzden lider olan, açık pazarın sürdürülmesinde uzun dönemli borç verebilme kapasitesine ve özellikle kriz süreçlerinde fiyat indirimlerini sağlayabilme yetisine sahip olmalıdır. Bu yüzdendir ki, böylesine bir gücün noksanlığı, 1929 krizinin bu denli uzun ve derin olmasına sebep olmuştur (Kindleberger, 1973: 291-308). Tüm bu bakış açısı çerçevesinde, bu lidere hegemon ve hegemonun önderliğindeki bu sistemin işlerliğini savunan yaklaşıma da hegemonik istikrar görüşü denilmektedir. Kriz dönemlerinde ise hegemon olan aktör sorumluluğu gereği problemlerin üstesinden gelebilmek için askeri gücün katkısını da bu sürece eklemesi gerekmektedir. Sistem, sadece ekonomik güç odaklı olmamaktadır. Hegemonik istikrar görüşüne bu akademik katkıyı öncelikle Robert Gilpin'in çalışmaları yapmıştır. Böylelikle, realist/neorealist ve liberal/neoliberal bir sentez ile maddi unsurların öncelikli olduğu bir görüş haline gelmiştir.

Gilpin'nin Global Political Economy eserinde (2001) vurguladığı üzere, genel hegemonik istikrar görüşü, hegemonun gerekli olduğu askeri ve ekonomik kapasiteye sahip olan bu liderin diğer aktörler üzerinde kontrol sağlayabileceği, böylelikle de istikrarın sağlanacağı savına dayalıdır. Diğer aktörlerin hegemon olana rıza göstermelerine kaynaklık eden neden ise, sermayenin ulusaşırı olduğu bu küresel ekonomik yapıda, hegemonun sağlayacağı çıkarın diğerlerinin de faydasına olacağıdır (Gilpin, 2007: 21-37). Hegemon gücün büyük bir kapışma sonunda değişeceğine inanan Gilpin, başka bir hegemonun doğması sistemin bir öncü tarafından koordine edildiği gerçeğini değiştirmez görüşüne de inanmaktadır (Griffiths, 2011: 19-22).

Hegemonik istikrar görüşünün, ekonomik gücün askeri kapasite ile korunması yaklaşımı bazı ekonomi uzmanlarınca özellikle desteklenmiştir. Bunlar arasında; Barry Eichengreen, Robert Mundell, Bruno Frey ve Mancur Olson öne çıkmaktadır. Eichengreen, serbest piyasa ekonomisinin oluşumunda hegemonun rolüne vurgu yapmıştır. Çalışmasını, hegemon aktörün gücünün yükseliş 
dönemleri üzerine yapmıştır. Eichengreen' e göre uluslararası işbirliği ile birlikte hegemon öncülüğünde işleyen bir uluslararası para sistemi vardır. Hegemon konumda olan aktör, güç bakımından düşüşe geçtiğinde ise çok taraflı ve bölgesel anlaşmaların kapısı açılacak, böylelikle çok kutuplu yapı oluşabilecektir (Eichengreen, 1987:1). Bu bağlamda bu çok kutuplu yapı, çok sesliliği getireceğinden dolayı da istikrar bozulacaktır. Özetle hegemonya hem gerekli, hem de zorlayıcılık faktörünü kullanabilen irade dayayıcı güç olabilmektedir. Ancak şu da bilinmelidir ki bu yorumun Hegemonik istikrar görüşünü yansıtmadığı eleştirisinde bulunan Gilpin, hegemonik sisteme rıza ile sağlanan katılımda, rıza sebebinin uluslararası kamu mallarına yapılan katkı ve getirisi olduğunu savunmaktadir (Gilpin, 2001:93).

Diğer bir ekonomi uzmanı Robert Mundell, benzer bir şekilde uluslararası para sistemindeki işleyişin istikrarını bir hegemonun sağlayacağını savunmaktadır (Mundell, 1983:189). Ayrıca kamu mallarının piyasaya sunumunun sağlanmasını yine bir hegemonun sağlayacağını savunan Robert Baldwin ve Bruno Frey de, hegemonik istikrar görüşünün ekonomik açıdan savunucularındandır (Baldwin, 1993).

Hegemonyayı, sistem işleyişindeki gerekliliğini ekonomik açıdan ticari bariyerlerin indirilmesi açısından inceleyen Mancur Olson ise, hegemonun ticari bakımdan diğer aktörlere baskı yaparak bu bariyerlerin indirilmesini sağlayabildiğini savunmaktadır. Böylelikle ekonomik işleyiş açıklık kazanabilecektir (Olson, 1986:89). Hegemonya gereklidir. Çünkü hegemon aktör, konumunu kullanarak baskı yöntemleri ile pazar işleyişini sekteye uğratabilecek engelleri bertaraf edebilecektir. $\mathrm{Bu}$ engeller; diğer devletlerin talep edebileceği ticari kota, bariyer, ek vergilendirmeler gibi uygulamalardır. Diğer yandan Olson'a göre, hegemon konumda olan aktör diğerlerine oranla kamu mallarından en büyük payı almalıdır (Snidal,1985: 581).

Hegemonik istikrar görüşü, işbirliğinin de gerekli olduğunu savunmaktadır. Şöyle ki, işbirliği bir takım normlar ve kuralları gerektiren bir yapıya ihtiyaç duymaktadır. $\mathrm{Bu}$ da rejimler denilen bir kurallar bütününü oluşturmaktadır. Ancak burada, özellikle liberal kurumsalcı bakış açısını savunanların aksine, hegemonun gerekliliği, süreklilik arz eden bir durumdadır. Hegemon olmaz ise sistemin kurallarına uymayı teşvik edecek otorite boşluğundan istikrarsızlık oluşabilecektir (Gilpin, 2001:97). Dolayısıyla hegemonik istikrar görüşündeki işbirliği anlayışı, ancak bir hegemonun varlığ ile sürdürülebilir. Ancak liberal kurumsalcı yaklaşımın işbirliği anlayışı, hegemon aktör zayıflasa ve çökse de devam edeceğine yöneliktir.

İşbirliğinin oluşma sebeplerine bakıldığında, yine ekonomik ve güç odaklı kazanç dönüşümü önemlidir. Bu durum, uluslararası kamu mallarının işleyişi ile açıklanabilir. Neorealist açıdan, kamu mallarının hegemonun önderliğinde piyasaya sunulması ve istikrar odaklı çalışmasını ele alan yine Kindleberger olmuştur. 1986 yılında, hegemonya ve işbirliği konulu çalışmalarının özü, uluslararası kamu mallarının bir hegemon tarafından sunulacağına dayanmaktadır (Kindleberger, 1986:1-13). 
Ancak, bir devlet içerisinde olan kamu mallarının, vergilerle karşılanması durumuna, uluslararası perspektiften bakıldığında, sistemin anarşik yapısında devletlerin vergi ödediği merkezi bir yönetim yapısı bulunmamaktadır. Dolayısıyla, bu görevi işbirliği çerçevesinde oluşturulan uluslararası kuruluşlar yerine getirmektedir. Böylelikle hegemonik istikrar görüşü bakımından kamu mallarının piyasaya sunulması, hegemon önderliğinde koordine edilirken, buna diğer aktörlerin işbirliği içerisinde rıza göstermesi de sistemin diğer aktörlere de kazanç sağlayacağı yapı gereğidir.

İşbirliğine ve uluslararası ekonomik yapıya katkı ile orantılı olması beklenen kazanç dağılımında farklıklar olması, çatışmaları doğurabilmektedir. Ancak, hegemonik istikrar görüşünün savı uluslararası ekonomik yapıya katkıyı en az sağlayanın dahi bir kazancı olacağı ya da hiç katkı sağlamayanın dahi dolaylı yoldan kazanım sağladığı görüşü, bu çatışmanın sebebidir. Buna açıklık olarak, görüşü savunanlar, bunu yine hegemon rolde olan aktörün gücünü kullanarak sisteme katk1 yapmaya zorlayacak olan otoritesini göstermektedirler (Norrlof, 2010:31). Devletlerin özgür iradelerine bağlı olan işbirliğine ve uluslararası ekonomik yapıya katılım, hegemon kontrolünde teşvik edilmelidir. Aradaki adaletsiz ve çatışmacı durumu da yine hegemon konumda olan düzene koymalıdır. Neoliberallerin açısından olduğu gibi mutlak kazanç olarak değil, sistemden herkesin göreceli bir kazanım elde edeceği bakımından bakmaktadırlar.

Çatışma ve savaş açısından bakıldığında, hegemonik istikrar görüşünün çatışma ve güç dengesi klasik realizm ile örtüşmektedir. Güç dengesi üzerinden savaş yolunun açık olabildiği bir ortam söz konusudur (Copeland, 2012:50). Dünya savaşlarının hegemonik sistemin olası bir sonucu olduğu vurgulanmaktadır. Gilpin'in bu konuda vurguladığı gibi, hegemona karşı yükselen bir gücün çatışması durumunda dengeler bozulabilir, buna diğer aktörlerin katılımı ile bir dünya savaşı ortaya çıkabilir. Bu durum ise Gilpin tarafından Hegemonik Savaş Teorisi-Theory of Hegemonic War yaklaşımı ile açıklanmaktadır (Gilpin, 1988:591-613). Bu bakımdan, siyasal ve ekonomik olarak, uluslararası ilişkiler sisteminin korunması ve yönlendirilmesi bir öncü tarafından olmalıdır ve böylelikle istikrar sağlanabilecektir.

\section{b. Liberal Kurumsalcı Yaklaşım}

Liberal Kurumsalcı bakış açısında uluslararası sitemin iç içe yapısına bir vurgu vardır. Devlet dışı aktörlerin etkisinin de incelendiği görüşe göre, sistem çoğulcu yapıda ve bir hegemonun öncülüğündedir. Neorealistlerden ayrıldığı nokta; işbirliği, kurumsal mekanizmalar, rıza unsuru, gönüllülük faktörleri, rejimler ve sistemin hegemon konumdaki aktör dişında dahi işleyen özüne yöneliktir. Neorealistlerce savunulan göreceli kazancın mutlak kazanç olarak yorumlandığı bu görüş eleştiri alsa da, savunmalarını karşılıklı bağımlılığın kaçınılmaz yapısıyla yapmaktadırlar. Devletlerin özgür iradeleri ile yapmış oldukları katılım, işbirliğini ve kurumsal bir yapıyı doğurmaktadır. Hegemon aktör bu yapının kurallarını belirleyerek bir rejimler düzeni oluşturmaktadır. Görüşe göre, bu düzen, hegemon düşüşe geçse dahi işlerliğini sürdürecektir. 
Liberal kurumsalcı yaklaşımının ilk çalışmaları, neorealizmin realizmden revize edildiği ve Amerikan hegemonyasının düşüşe geçtiği 1970'li yılların kriz döneminde olmuştur. Gerçekçi ve liberaller arasında oluşan görüş ayrılıklarının yoğunlaştığı bu süreç, dünya savaşları ardından sistemin istikrar arayışında olduğu ve giderek birbirini etkileyen aktörlerin belirdiği dönemdir. Ayrıca hegemonyanın düşüşü ve yükselişi üzerine yapılan akademik çalışmalar öne çıkmaktadır. Çünkü güç algısını hegemonya ve onun ön koşulları üzerinden yorumlayan yaklaşımlar, zorlama ve rıza gösterme üzerine uluslararası aktörleri analiz etmeye yoğunlaşmıştır.

$\mathrm{Bu}$ tartışmaların kaynağını ise I. Dünya Savaşı sonrası dünya savaşlarının nedenleri, sonuçları ve önlenebilirliği üzerine bir arayışın olmasıdır. Norman Angell'in I. Dünya Savaşından hemen önce kaleme aldığı Büyük Yanılma-Great Illisuon çalışması, sanayileşen devletlerin ortaya çıkmasından ve bunların birbirine ekonomik olarak ilintisi olduğundan dolayı savaştan kaçınılacağı üzerinedir (Angell, 1911). Ancak I. Dünya Savaşının gerçekleşmesi bu çalışmanın realistlerce ütopyacılık olarak eleştirilmesine sebep olmuştur. Ardından gerçekleşen liberal kurumsallaşma süreci, neoliberal görüşlerin yayılmasına vesile olacaktır. Ancak II. Dünya Savaşının olması neoliberallerin bu sefer özellikle Edward Hallet Carr gibi realistlerce entelektüel ütopyacılar olarak eleştirilmesine sebep olmuştur (Carr, 1946:7-10). Güç yorumlaması ise; hegemonya kavramı üzerinden neoliberallerin kurumsal yapı, ikna ve özgür irade ile sisteme katkı ve işbirliği odaklı savlarıyla, özellikle Robert Keohane, Joseph Nye ve John Ikenberry tarafından analiz edilmektedir.

Liberal kurumsalcı yaklaşım, uluslararası organizasyonların etkisine değinmektedir. Bu bakımdan rekabetçi yapı daha stratejik bir hal almaktadır. Teknolojik ilerlemeler sadece askeri güç kapasitesine katkısı bakımından değil; ekonomik, kültürel ve sosyal bir rekabet bakımından da değerlidir. Enformasyon, öne çıkan rekabet unsurları arasına girmiştir. Teknolojik gelişmeler ve enformasyon artık uluslararası kamu malları kategorisine girmektedir (Gilpin, 2001:107). Bu da teknolojik gelişmeler ve enformasyonun elde tutulması üzerinden ciddi bir rekabet ortamını doğurmaktadır. Diğer aktörlerin takip edilmesi, güç elde etmek isteyen aktörün de kendi imajını etkili tasarlayabilmesi gerekmektedir. Zira diğer aktörlerin ikna edilmesi öne çıkan bir durumdur. Bahsi geçen bu gelişmeler liberal kurumsalcı yaklaşımın öne çıkan rekabetçi, küresel ve katılımcı bir uluslararası ilişkiler yaklaşımının kaynaklarındandır.

Liberal kurumsalcı yaklaşımda askeri güç unsuru önemli olmakla birlikte ilk sırada yer almamaktadır. Askeri güç, mevcut hegemonyanın olası tehdit içeren durumlarda koruması olarak muhafaza edilmektedir. Askeri güç, kriz dönemlerinde ve özellikle ekonomik aktivitenin engellenmesine yönelik tehditlerde caydırıcılık bakımından gereklidir. Burada özellikle vurgulanması gereken durum, askeri kapasitenin diğer aktörlere tehdit oluşturacak bir seviyede olmamasıdır. Ekonomik bölgelerin korunması adına yeterli bir seviyede tutulması gerekmektedir. Aksi durumda bu durum hegemon konumda olanın tehdit olarak görülmesine ve çatışmaya sebebiyet verecektir. Ayrıca 
işbirliği oluşturulması adına zayıf müttefiklerin katılımı teşvik edileceğinden, askeri imajın uygun seviyede olması bu zayıf müttefiklerin hegemon konumda olan aktörün direktiflerine rıza göstererek uymalarına engel olmayacaktır (Keohane, 1984: 40,135,138).

Öncü aktör kendi imajını oluşturarak diğer aktörlere bir örnek sunmaktadır. Hegemon aktör, işbirliğinin gücünden yararlanmaktadır. İşbirliğgi, uluslararası bir kurumsallaşma anlamına gelmektedir ve hegemon tarafından oluşturulmaktadır. Bu yapı öylesine bağlantılıdır ki sistemin birbirine bağlantılı halinde tüm aktörler, görevlerini yerine getirerek katılıma meyledeceklerdir. Hegemon konumda olan aktörün, koordine edici gücünde azalmaya gidilse dahi, kurumsal mekanizma işleyecektir ve istikrarı devam edebilecektir. Bu bakımdan neoliberallerin en önemli savunmaları Amerikan hegemonyasının 1970'li yılların kriz döneminde düşüşe geçmesine rağmen ABD’nin uluslararası ekonomik sistemde kalmaya devam etmesidir.

Uluslararası sistemde ana aktör olan Ulus-devletlerin sonuna gelindiğine yönelik tartışmalarda, devletler halen daha karar alıcılardır. Ancak, rollerinde ve uluslararası ilişkilerdeki politik yöntemlerinde boyut atlamaları yaşanmaktadır. Bu konulara özellikle vurgu yapan Keohane; ulusüstücülük, uluslararası işbirliği ve örgütlenme konularına uluslararası ilişkilerin işleyiş biçimi bakımından değinmektedir. Keohane’ye göre (1984:6), ekonomik olarak çıkarların dağılımı ve ortak kazanç faktörü işbirliğinin sonuçları arasındadır.

İşbirliği vurgusu öylesine öne çıkmaktadır ki, hegemonik istikrar görüşü savunucularından özellikle bu noktada ayrılmaktadır. Ancak Keohane'nin After Hegemony eserinde de (1984: 35-38) vurguladığı üzere, karşılıklı bağımlı yapısından dolayı hegemonyadan sonra dahi diğer aktörlerin çıkarından dolayı sisteme katılım devam edecek ve istikrar sürdürülecektir. Devletlerin bu kurumlara ihtiyaçları vardır. Dolayısıyla bu da, kurumların kuralları, işleyişi ve düzenlemeleri bütününü oluşturan rejimlerin önemini göstermektedir (Johnson ve Heiss, 2018: 123-130).

Rejimler, literatür kullanımı olarak, 1970'li yıllarda ilk kez John Ruggie tarafından uluslararası ilişkilerin uzun dönemli hukuksal mekanizmalarının oluşturulması maksadıyla çalışılmıştır (Haggard ve Simmons, 1987: 491-517; Barschdorff, 2001:10). Ruggie (1975: 79-415 ), rejimlerin hukuksal boyutuna vurgu yaparak katkı sağlarken Krasner bunu geliştirerek stratejik politikanın sistematiği açısından yorumlamıştır (Krasner, 1982:2). Krasner'ın rejim tanımı; aktörlerin belirli bir alana yönelerek uygulamayı taahhüt ettikleri normları, prensipler, kuralları ve karar-alma süreçlerinin uygulanış biçimlerini belirten sınırlamalar şeklindedir (1982:185-205).

Rejimler, dar anlamlı anlaşmalar olarak değerlendirilmemelidir. Rejimler; daha kapsamlı olarak, uzun vadeli amacı olan, düzenlemelerin genel hattını ifade etmektedir. Bu bakımdan ikili, çok taraflı ya da bölgesel nitelikli olan anlaşmalardan ayrışmaktadır (Keohane ve Nye, 1987: 725-753). Uluslararası örgütlerle rejimler arasında ince bir çizgi vardır. Örgütlerin bütçe yapmak ve eyleme geçebilmek gibi bir hareket sahası varken, rejimler daha çok bu eylemlerin işleyiş biçimini 
şekillendiren kurallar ve sınırlar zincirini oluşturmaktadır (Keohane, 1988: 393). Örneğin, Bretton Woods sistemi bir rejimdir ya da BM'nin çevreye yönelik oluşan düzenlemeleri çevre rejimidir.

Liberal kurumsalcılar, ulusaşırıcılık kavramının hegemonik sistemde değerlendirilmesi gerektiğini savunmaktadır. Keohane ve Nye ulusüstü yapıdan farklı olarak, devletin tek temel aktör olmadığı, devletlerin üstünde bir otoriteye atıf yapmaktadır. Devletler, uluslararası ilişkileri şekillendiren aktörlerdir, ancak ulusaşırı yapıların da uluslararası ilişkileri yönlendiren etkenler olduğu savunulmaktadır. Bu yapılar; devletdışı ulusaşırı kuruluşların, devletlerin ve devletlerin bir araya gelerek oluşturdukları ulusüstü organizasyonların oluşturduğu, bir devletten bağımsız ve karmaşık yap1lardır (Nye,1971:329-349).

Ikenberry (2001:17), da hegemonyadan sonra dahi istikrarın devam edeceğini savunmaktadır. Bu görüşünü desteklemek için Amerikan hegemonyasında düşüşe geçilen 1970'li yıllarda dahi ABD’nin fayda sağlayıcılığının sürdürülmesini örnek göstermektedir. Bu bakımdan uzun vadeli faydacılık, kurumsal örgütlenmeyi öncülük ederek oluşturan hegemona özel bir durumdur. Uzun vadeli faydacılığın sebebi, hegemon konumda olan aktörün gücünde yine kendi irade ve öncülüğü ile kısıtlamaya yönelmesidir. Bu bakımdan Ikenberry, güç dengesi açısından neorealist; kurumsal mekanizmalara önceliği bakımından da neoliberal bir görüş arasında denge kurmaktadır (Johnson ve Heiss, 2018.).

Hegemonya kavramını uzun vadeli kazanımlar adına manevi değerler üzerinden ele alan yaklaşım yumuşak güç kavramı olmaktadır. Nye'in bu yaklaşımı, dış politikada şiddete ve yaptırıma başvurmadan diğer aktörlerin rızasını alarak uygulamalara dayalıdır. Böylelikle, uzun vadeli kalıcı sonuçlar sağlanacağını savunmaktadır. Bir devletin kazanmak istediğini elde edebilmek için, bunun diğer aktörlerin de istediği hedef olduğu yönünde stratejik bir alg1 oluşturmak, yumuşak gücün yöntemidir. Bu bakımdan dış politikada davranış biçimleri kayda değer önemde olmaktadır.

Nye, en genel ifade ile bir devletin diğer aktörleri kendi istediği gibi hareket etmesini sağlayabilme yetisine güç demektedir (Nye, 1990:153-171). Böylelikle, öncü rolde olan aktör tercihleri şekillendirmektedir. Dolayısıyla kendini ideal öncü olarak sunmalıdır. Araç olarak özellikle kültürel değerler, ideolojiler ve kurumlar kullanılmaktadır.

Özellikle 11 Eylül sonrası sert gücün dış politikada hegemonik değerlere zarar verdiği sonucuna varıldıktan sonra, yumuşak güç daha değerli bir konuma gelmiştir (Nye, 2005:12). Bu bakımdan Amerikan hegemonyasının gücü için sert gücün kullanımı bakımından bir dengenin olması gerekmektedir. Nye, bu durumu Amerikan Gücünün Paradoksu eseriyle (2002) yumuşak gücün gerekliliği bakımından vurgulamıştır. 11 Eylül sonrası dönemde görülen Amerikan hegemonyasındaki etki düşüşü, Bush'un sert güç politikalarıyla ilişkilendirmiştir (Nye, 2004:16-20). Böylelikle yumuşak güç kaynaklarının diğer aktörlerce kullanılarak karşı bir etki yaratabileceği de unutulmadan, dengeli bir dış politika, uzun vadeli sonuçların öncelikli yöntemleridir. Buradan da 
anlaşılacağı üzere Nye'a göre, Amerikan hegemonyasında dönemsel bir düşüşün söz konusu olduğu, ki bu Bush dönemine bağlanmaktadır, ancak bu düşüşün mutlak bir düşüşe henüz sebebiyet vermediği savunulmaktadır (Nye, 2015:20).

Sert güç varlığını korumalı, dış politikadaki koşullara göre dengeli bir yaklaşım izlenmelidir. Bu da Nye tarafından akıllı güç denilen bir dengeleme ile tanımlanmaktadır (Nye, 2009:160-163). Yumuşak güç, hegemonyanın riskli olduğu dönemlerde öne çıkarılması gereken bir yaklaşım tarzıdır (Guzzini, 2006:125). Hegemonik kontrol sağlayabilmede meşru bir alana ihtiyaç vardır. Bunun için diğer aktörlere sunulan seçeneklerde özgür iradeleri ile seçim yapmaları istenmektedir (Hayden, 2012). Yani aktörler özgür iradeleri ile seçenekler arasından seçim yaparak hegemon aktörün kontrolüne razı gelirler.

\section{c. Eleştirel Yaklaşım: Neogramsci Bakış}

Hegemonya kavramının kapitalist sistemin oluşturduğu ekonomik sınıflar üzerinden ele alınış biçimi eleştirel bir yaklaşımı oluşturmaktadır. Hegemonya kavramını akademik literatüre sokan, sosyal sınıfların hâkimiyeti ele geçirme biçimlerine değinen ve aynı zamanda Hapishane Defterleri eserinin (1997) sahibi olan Antonio Gramsci’dir. Gramsci'nin eleştirel yorumlaması diğer teorik görüşlere kapı açmaktadır. Direkt olarak uluslararası ilişkiler incelemesi yapmayan Gramsci, hegemonyayı alternatif devlet yapısı oluşturması bakımından sivil toplumun gücü ve ideolojiler etrafinda toplanan politik ilişkiler bakımından ele almaktadır (Cox, 1993: 1-18). Yaklaşımını Marksist perspektiften (Robinson, 1983:23), İtalyan devlet yapısı üzerinden ele almıştır. Cox ise hegemonya kavramını uluslararası ilişkiler disiplini çerçevesinde ele almıştır (Bieler ve Morton, 2004:85-113). Böylelikle hegemonya kavramının sosyal sınıfların hâkimiyet alanını ele geçirme koşulları ve gücü sürdürme biçimleri uluslararası ilişskiler açısından irdelenmiştir (Anderson, 1988:36-37).

Neogramsci yaklaşımında hegemonya ideolojik bir sürecin ardından oluşmakta ve toplumun rızası sağlanarak entelektüel ahlak, kültür ve ikna etmeyi bir arada tutan bir bağlantıdan oluşmaktadır. Ancak hegemonya zor kullanımı ile takviye edilebilmektedir (Robinson, 1998: 22). Böylelikle zor kullanımının tehdidi ile rıza sağlanan unsurlar garanti altına alınmaktadır. Hâkim sınıfın çıkarları, tüm toplumların çıkarları olarak yansıtılır. Buradaki hegemonya, gücünü diğer devletlerin sosyal sınıflarına da hitap ederek, onları ortak bir noktada buluşturmasından almaktadır (Eralp, 2004: 176). Bunun için toplumu bir araya getirecek bir bağ bulunur. Genellikle, değer yargıları ya da ideolojiler olarak seçilen bu bağ, alt ve üst sınıflar arasında tutkal görevi görmektedir (Jessop, 2005:181). Bu oluşan kesişim alanları tarihsel blok denilen toplumsal birliktelikleri oluşturur. Diğer yandan, hegemona karşı bir başkaldırı niteliğinde olan ayrışmalar ise hegemonik yapıda yenileşme ve sakinleştirme olarak nitelendirilebilecek politikalarla pasif devrim yapılarak hegemon tarafından egale edilmektedir (Morton, 2011: 68). 
Cox’un hegemonyayı ele alış biçimi üç ana yapıya bağlanmaktadır. Bunlardan ilki maddi kaynaklar, ikincisi kurumlar ve sonuncusu ise fikirlerdir (Cox, 1987:6-7). Ekonomik veya teknolojik değerler olarak maddi kaynaklar ele alınırken bu durum, üretim biçimine ve sınıfların oluşumuna etki etmektedir. Kurumlar ise hegemon aktörün hareket sahasına hizmet ederken, fikirler bu toplumsal yapıları bir araya getirmede kullanılır (Sinclair, 1996:10). Tüm bu çerçevede hegemon olan sadece kendi çıkarını değil, diğerlerinin çıkarını da hesaba katarak ilişkiler kurarsa, zora başvurma ihtiyacı duymadan itaat sağlanmış olur.

Cox’a göre, uluslararası ilişkiler açısından diğer devletlere oranla daha güçlü olan bir devlet diğer devletteki vatandaşların çıkarlarını da savunduğunu gösterebilirse hegemonyasını kurabilecektir. Dolayısıyla, Gramsci'nin iktidarı ve hegemonyayı kullanım biçimi dünya ölçeğine büründürülmüştür. Direniş faktörü, ortak ideolojilere olan güven ile devletlerin ve o devletteki sınıfların kendi iradeleri ile destekledikleri bir hegemonya olacağından ortadan kalkacaktır (Cox, 1981:126-155.).

\section{d. Dünya Sistemleri Yaklaşımı}

Hegemonya kavramını diğerlerinden ayrı bir değerlendirme haznesine sokan bakış açısı, sistemci yaklaşımdır. Özellikle dünya-sistemleri yaklaşımının hegemonyayı ele alış biçimi; aktörlerin, gücün, örgütlerin ve sınıfların ayrı ayrı incelemesinin özel bir kıstas olarak görülmediği, döngülerin tekrarlanan mekanizmasında genel bir üst yapı incelemesi yapıldığı bir perspektiftir.

Dünya sistemleri yaklaşımında değişim ön plandadır. $\mathrm{Bu}$ yaklaşım, ekonominin uluslararası ilişkilerin temeli sayıldığı ve sermaye üretiminin güç çıkışlarına ve belirli bir süre sonunda aşırı yayılma ve büyük savaşların neticesinde güç çöküşlerine yol açtığını savunan bir yaklaşımdır. Dolayısıyla, asıl irdelenmesi gereken bu döngülerin kendisidir. Uluslararası ilişkilerin genel sistematiği olarak her döngü sonrasında bir önceki güç çöker ve diğeri hegemonik yükselişine geçer. Dünya sistemleri incelemeleri yapanlar arasında Immanuel Wallerstein, Andre Gunder Frank, Barry K. Gills, George Modelski ve Paul Kennedy gelmektedir. Realist ya da Marksist açıdan farklı felsefeler üzerinden incelemeler yapsalar da birleştikleri ortak nokta belirli bir birikim sonunda yükseliş ve çöküşe dair hegemonik döngülerin tekrar etme durumudur.

Wallerstein'in (2004: 58-59) dünya-sistemi yaklaşımını Marksist değerler üzerinden irdelemektedir. Yaklaşımı, teorik bir sunuştan ziyade bir analiz biçimi olarak değerlendirmek daha doğru olacaktır. Çünkü tarihsel analizin yapıldığg ve güç değişimlerinin ortak noktalarının saptandığı bir teknik biçimidir (Wallerstein, 2003:13). Ayrıca, Wallerstein'in bilime bakış açısı genellikle bütünselliğe yönelik olmaktadır. Bilimdeki bölünmeleri savunmayan düşünür, hegemonya kavramını da sosyal bilimlerin bir inceleme alanı olarak ele almış ve diğer bilimsel destekleri sosyal bilimlerin tek çatısı altında incelemeyi seçmiştir. Ona göre (1999: 7-10), sosyal bilimler tek bir inceleme alanıdır. 
Wallerstein, kapitalizmi modern dünya sistemi olarak yorumlamaktadır ve bu sürecin başlangıcını sermaye birikiminin oluştuğu 500 yıl öncesine dayandırmaktadır. Bu bakımdan dünyada farklı sistemler var olmuştur, ancak bizim yaşadığımız sonuncusu olan modern dünya sistemidir (Wallerstein, 2011: 66-70). Wallerstein, dünya-sistemleri ile farklı sistemlerin varlığını savunurken, Andre Gunder Frank ve Barry K. Gills (1993: 3-6) ise bu sermaye birikimi başlangıcının 5 bin y1l öncesine dayandırıldığı tek bir dünya-sistemi vurgusu yapmaktadır. Bu açıdan Wallerstein bakışıyla, 500 yıl öncesinden başlayan sistem oluşumu bugün Amerikan hegemonyasının öncülük ettiği bir kapitalist sistemdir.

Hegemonya'yı döngüsel sistemler açısından irdeleyen bu düşünüler, bağımlılık yaklaşımı ile, devletlerin kapitalist sistemde merkez ve uydular olmak üzere bir etkileşimde olduğunu savunmaktadırlar. Frank'ın gelişmiş devletlere az gelişmişlerin bağımlılığı üzerine olan bağımlılık yaklaşımı, Wallerstein tarafından yarı-çevre de eklenerek geliştirilmiştir. Yarı-çevre, gelişmiş devletler ile gelişmemişler arasındaki geçişi sağlayan bir geçiş ülkeler dizisidir (Wallerstein, 1995:26). Böylelikle, hegemon konumda olan öncünün yer aldığı gelişmiş çevre grubuna, ara mal ve hizmet geçişini sağlayan ve gelişmemişler ile gelişmişler arasındaki sosyolojik bir yumuşak geçişi sağlayan yarı-çevre grubu, hegemonyanın sürdürülmesi adına önemlidir. Ancak, istikrar yine de hegemon tarafından sağlanır (Wallerstein, 1997: 67,84). Aslolan, bu hegemonun değişken olmasıdır. Hegemonya döngüsüne Modelski, siyasal güç birikimi açısından bakmaktadır. Ona göre, küresel bir güç birikimi ile oluşan hegemonyaların döngülerinde ekonomik güç ile politik-askeri güç kapasitesi birlikte kullanılmaktadır. Modelski’ye göre, küresel ölçekte olan ekonomik ve siyasal güç unsurları inceleme alanına alınırken, kültürel değerler gibi yerel unsurların uluslararası güç ve hegemonyal analizlerde ele alınmaması gerekmektedir (Modelski, 2005:3-30). Dolayısıyla siyasal-ekonomik ve askeri güç birikimi sonunda bir hegemon güç oluşur ve zayıf bir örgütlenme süreci sonunda gerileyerek çöker.

Kennedy'in sistemci yaklaşım yorumu, 1500 yılından itibaren hem ekonomik hem askeri etkinin güç çıkış ve belirli nedenlerle güç gerilemesine neden olan döngüler üzerinedir. Buradaki en büyük zayıflama nedeni, hegemon gücün aşırı yayılma ile bu yükü taşıyamayıp gerilemeye doğru gitmesidir (Kennedy, 2001:13-14). Savaşların sonucunda askeri harcamalar, ekonomik olarak hegemona bir yük bindirecektir. Güç yükselişi bu yükün göze alınmasıyla ile ilgili değil, bu ekonomik harcamayı kullanmaktan çekinip çekinmeyeceği ile ilgilidir.

\section{HEGEMONYADA TEORİK ÇATIŞMA}

Uluslararası ilişkiler sosyal bir bilim dalı olmasından dolayı ölçülebilir değerleri kısıtlı bir alandır. Hegemonya kavramı da bu bakımdan hem maddi değerlerin bir güç unsuru olarak yorumlandığı hem 
de soyut olguların bir güç kaynağı olarak yorumlandığı görüşler bakımından farklılaşmaktadır. Hegemonyaya atfedilen nitelik, her bir görüşe göre farklı biçimsel özellikleri barındırmaktadır. Hegemonya kavramı anlam olarak güç bakımından üstünlük ve tahakküm gücü olarak basite indirgenirse, uluslararası ilişkiler bakımından bu üstünlüğü elde etme biçimlerinde araçsal olarak çeşitlilik ve değişimler söz konusu olmaktadır. Uluslararası ilişkiler alanında hegemonya odaklı analizler çeşitlenmiş ve teorik görüşlerin birbirlerine yönelik eleştirel bakış açıları literatürü güçlendirmiştir. Hegemonyanın oluşmasında ve özellikle sürdürülmesindeki şartlar her yaklaşımca farklı araçsal etkenler üzerinden ele alınmıştır.

Hegemonya kavramının tek bir görüş üzerinden mevcut uluslararası ilişkiler yapısını beklentileri karşılayacak şekilde analizi mümkün değildir. Çünkü, hegemonya kavramı bir teori değildir. Uluslararası ilişkilerde istikrar ve düzene yönelik hegemonya kavramını tatmin edici bir çerçevede tanımlayan genel bir teorik görüş de bulunmamaktadır.

\section{a. Hegemonik İstikrar Yaklaşımına Eleştiri}

Hegemonik istikrar yaklaşımının hegemonyayı ele alış biçimi maddi güç odaklı bir yaklaşım olduğundan eleştirisi, rıza unsurunun geri plana atan tarafıdır. Oysaki diğer aktörlerin özgür iradeleri ile alınan onayı hegemon konumda olan aktörün gücünün sürdürülmesinde daha uzun vadeli sonuçlara kaynaklık edecektir. Diğer yandan zor kullanımının tehdit olarak algılanması daha olası olduğundan hegemonyanın sürdürülmesinde daha fazla maliyet ortaya çıkacaktır. Dolayısıyla rızanın sağlanması ve ikna edilerek harcanan maliyet her anlamda sert gücün öne çıktığı maliyetten daha az olacak ve daha uzun vadeli sonuçlar sağlayacaktır.

Hegemonik istikrar yaklaşımının rıza sağlama durumu ile diğer yaklaşımların bahsettiği razı gelme durumları ayrışmalıdır. Hegemon kontrolündeki hegemonik sisteme teşvik, gerçek anlamda razı gelinme durumu olarak değil, sistemin buyurucu yapısından kaynaklı olduğu düşünülmelidir. Çünkü rıza göstermek farklı birçok alternatif arasından gönüllülükle yapılan bir seçimdir. Her geçen gün bireylerin daha da değerli olduğu çağımızda, farkındalık seviyesi artmaktadır. Bireyler daha katılımcı ve eleştirel olmaya başlamıştır (Uça Güneş, 2016:191-206). Bu ortamda, hegemonik istikrar yaklaşımının rıza sağlama durumu işlevsel olmayacaktır. Rıza, bu görüşe göre sadece ekonomik bir fayda ile sağlanacağı için diğer yandan özgürlük, hak, adalet ve manevi değerler için istikrarlı bir yapı talebinde bulunan toplumların isteklerine karşılık gelmemektedir. Dolayısıyla, hegemonyanın sorgulanması daha muhtemel olacaktır. Günümüz üzerinden bakıldığında, kamuoyların daha direnişe meyilli ve uluslararası sisteme katılımcı olması, Amerikan hegemonyasının zayıflamasından dolayı değildir. Çağın getirileri ile bireylerin daha aktif ve sorgulayıcı olması mevcut durumun eksiklerinin sorgulamasına neden olmuştur. Dolayısıyla, sadece devletler bazından bakılarak, ekonomik değerler ve küresel kamu malları üzerinden sağlanacak bir rıza, hegemonyal güç için yeterli olmamaktadır. 
$\mathrm{Bu}$ açıdan görüş, rıza sağlama durumunu kısıtlı seçeneklerde buyuruculuk ile sınırlı tutmakta, bu da uluslararası ilişkilerin güncel yapısı içerisinde eksik kalmaktadır.

II. Dünya Savaşı sonrasında ABD hegemonyasının oluşmasında sağlanan rıza, meşru bir alanı oluşturmuştur. Uluslararası örgütler, ABD hegemonyasının harekât sahasını meşrulaştırmıştır. Ancak bu örgütlenmeler sadece ekonomik ve askeri temelli değildir. Bu bakımdan sağlanan rızayı, askeri ve ekonomik temelli çıkarlara dayandırmak eksik bir yaklaşım olacaktır. Örneğin, hükümet dış1 uluslararası örgütler arasında olan 1961 yılından kurulan uluslararası af örgütü (UAÖ), özgürlük ve hak ihlali olduğu düşünülen devletleri raporlamaktadır (Power, 1981:16-17). Oldukça etkili olan bir örgüt olması ve raporlamalar ile yaptırım gücü olmamasına rağmen devletlerin olumlu bir imaj çizmeleri adına ülkelerini bu örgüte açmaları, hegemonik istikrar görüşü ile örtüşmemektedir. Ayrıca UAÖ’nün Batı merkezli olması, bağışçılarının çoğunun Batı ülkeleri olması, üçüncü dünya bağımsızlaşırken kurulması, Batılı devletlerle daha yakın işbirlikleri yapması gibi nedenler gönüllülükle kurulan bir örgütün kar amacı gütmeden hegemonyaya katkı yaptı̆̆ını gösterebilir (Byers ve Nolte, 2003:455-457). Dolayısıyla hegemonik istikrar görüşü ile sınırlandırılmış bir hegemonya tanımı eksik olacaktır.

Hegemonyaların ortalama ömrü yüzyıl (Modelski, 2005: 3-30). Dolayısıyla sadece maddi kapasite öncelikli bir yaklaşımla istikrar hedeflenmiş olunsaydı, hegemonik döngüler kısalır ve hegemonyalar sık sık değişebilirdi. Örneğin, 1970’lerdeki hegemonyasındaki krizi bertaraf edebilmek için ABD, neoliberal küreselleşmeye önem verdiği kadar kültürel küreselleşmeyi de bir araç olarak kullanmıştır. Eğitim değişim programları ve kamu diplomasisi gibi kavramlara yönelmiştir (Foreign Affairs National Archives), (Melissen, 2005: 4). Devlet karar alıcıların ikna edilmesi kadar halkların ikna edilmesi de önemli olmuştur (Köksoy, 2014: 211-231).

Yaklaşımın ana hatlarında bireyselliğin uluslararası ilişkilere etkisi göz ardı edilmektedir. Hegemonya oluşumunda meşruluğun uzun vadeli sağlanmasındaki en önemli kaynağın diğer aktörlerin rıza göstermesine dayandığı düşünülürse bu bakımda eleştiriye açık kalmaktadır. Ayrıca uluslararası aktörlerin özellikle soğuk savaş sürecinde ve sonrasında çeşitlenmeye başlaması incelendiğinde hegemonik sistemde sadece ulus-devletlerin etkili olmadığı görülecektir. Yumuşak güç ve uluslararası halkların ikna edilmesi hükümet seçimlerinde yönlendirici dolaylı bir etkiye sahip olduğu, böylelikle uluslararası ilişkilerde etkili olduğu görülmektedir.

Hegemonik istikrar yaklaşımının içerisinde var kabul edilen işbirliği kaynaklı kurumsallaşmış yapıları hegemon kendi polis gücü veya finansal yönetim şirketi gibi görmesi yine bu sistemin sorgulanması ve diğer aktörlerin hegemona karşı tavır almalarına sebep olacaktır. Örneğin, NATO’nun eylemlerinin Avrupa dışına çıkarılarak uluslararası polis gücü olarak gösterilmesi, özellikle Almanya ve Fransa gibi Avrupalı devletlerin eleştirilerine sebep olmuştur (Çelik, 2013:63- 
92 ). Hatta Libya konusunda, İngiltere ve Fransa, AB olarak Libya'ya müdahale edilmesini istemiştir (Louati, 2011).

\section{b. Liberal Kurumsalcı Yaklaşıma Eleştiri}

Liberal kurumsalcı yaklaşımının işbirliği, örgütlenme ve katılımcı uluslararası ilişkiler savunması hegemonik açıdan sürdürülebilir bir analizi içerebilir. Ancak diğer aktörlerin örgütlenme yoluna gitmek adına katılımın sağlanmasındaki kaynağın mutlak kazanç ve karşılıklı bağımlılığın olduğu savlarında eleştiriye açık alan kalmaktadır. Zira koordine edici yetki hegemona ait olmasına karşın hegemonun gücünde azalmaya gitmesi durumunda uluslararası düzenin uzun vadeli istikrarının işlemesinin sağlanamama olasılığı vardır. Bu süreç, rakip hegemon aktörlerin yükselişte olduğu geçici bir süreçtir. Dolayısıyla liberal kuramsalcıların hegemon çökse dahi sistemin işbirlikçi ve kurumsal yapısı sayesinde işlemeye devam edeceği savına karşılık sistem döngüsel olarak bir öncüye ihtiyaç duymaktadır.

Avrupa Birliği’nin kurulmasından sonra ekonomik olarak bir dev ancak siyasi olarak bir cüce olarak nitelendirilmesi liberal kurumsalcı yaklaşımda yapmış olduğu katkıyla doğru orantılı bir kazanca sahip olmadığındandır (Salmon, 2004: 447-468). Dolayısıyla zamanla hegemonyanın sorgulanması sürecine gidileceği sonucuna varılabilir. $\mathrm{AB}$ özellikle Balkanlarda ve Filistin gibi bölgelerde hegemon konumda olan ABD'den daha fazla katkı sağlamaktadır (European Union Committee Further Enlargement Report, 2006). Elbette ki bunu yapmaktaki gaye kazanç hesaplamasında Birliğin gücünü arttırmaktır. Ancak AB'nin daha fazla kaynak aktarmasına rağmen daha az siyasi etkiye sahip olması, liberal kurumsalcı yaklaşımın savları ile açıklanamamaktadır. Bu durum, AB üyelerinden kimi aktörleri rahatsız etmekte ve ikna-rıza olgusu sorgulanmaya başlamaktadır. Bu da askeri açıdan bu Avrupalı devletleri güce meyillendirebilir ve liberal kurumsalcı yaklaşımın genel savı eleştirilebilir. AB'nin (özellikle İngiltere ve Fransa) Libya konusundan NATO olarak değil de AB olarak bir askeri müdahale yapmak istemeleri bu sorgulamanın ve birlikte yaşanan çatlağın bir örneğidir (Louati, 2011).

\section{c. Eleştirel Yaklaşıma( Neogramsci görüş’e) Eleştiri}

Eleştirel yaklaşımın sosyal sınıfları ve üretim biçimine değinirken bu sınıfsal oluşumlarda kültür veya din gibi etkenler uluslararası ilişkilerde kullanılan tutkal unsurlar olarak geri plana itilmektedir. Diğer yandan din temelli örgütlenmeler ve bunun ticari boyutu bu görüş bakımından tanımsız kalmaktadır. Örneğin, Bazı AB üyeleri Türkiye'nin AB'ye sırt çevirdiği bir durumdan endişe ederek Türkiye'nin yeni müttefiklere yönelmesi durumunda AB'nin Hıristiyan bir kulüp olarak imajı süreceğini dile getirmiştir. İslam topraklarındaki İsrail-Filistin meselelerinde olduğu gibi sorunların çözüme kavuşturulmasında $A B$ 'nin başarısız olması durumunda, $A B$ ile İslam ülkeleri ilişkilerinin etkileneceği de düşünülmektedir (European Union Committee Further Enlargement Report, 2006). $\mathrm{Bu}$ bağıntılar etnik ve dini faktörler etrafından şekillenen dış politika öngörüleridir. Bu bakımdan 
eleştirel yaklaşımın sınıfsal ayrışması ve entelektüel ahlaka yoğunlaşan ikna süreci savları bu gibi durumları açıklamakta eleştirilmektedir.

Neogramsci bakış açısı, örneğin, Afrikan ve Amerikan etnik çatışmasındaki sebeplere; tahakküm biçimleri, boyun eğme biçimleri ve sömürü türleri üzerinden bakmaktadır. Yani yine sınıfsal boyun eğdirme ve kapitalist sistemin üretim biçiminden kaynaklı sömürüsüne dayandırmaktadır. Ancak bu bakış açısında, aynı devlet içerisindeki aynı sınıfsal konuma sahip kesimlerin etnik ve dini farklılığından dolayı çatışmalarını açıklamak eksik kalmaktadır. Örneğin farkıı etnik oluşumların siyasi katılımı farklı biçimlerde yaptığ 1 analizler vardır (Alonso, 1994:379-405). Etnik gruplar politik süreçte bir grup olarak ele alınmadığı düşünülse de örneğin Weber'e göre (1978) nasıl organize olduğuna bakılmaksızın ortak etnik inançta olanlar bir etki oluşturabilirler (Jain, 1996: 215-223).

Uluslararası aktörlerin bir araç olarak sık sık kullandıkları etnik unsurlar güç dengeleri adına etkili olabilmektedir. Üretim biçimi dışındaki oluşan gruplara manevi değerler üzerinden erişmek ve ikna etmek de mümkün olabilmektedir. Eleştirel yaklaşım savlarında fikirler üzerinden böylesine bir birleştirme söz konusu olsa da, bu sadece üretim biçiminden kaynaklı sınıfsal yapıların ihtiyaçlarına yönelik bir görüş ile sınırlıdır. Dolayısıyla hegemonya kavramının ve günümüz uluslararası ilişkilerindeki güç dengelerini tanımlamada eksik kalmaktadır.

\section{d. Dünya-Sistemleri Yaklaşımına Eleştiri}

Dünya-sistemleri yaklaşımı açısından ele alınan hegemonyanın döngüselliği vurgusunda, hegemonyanın oluşumundaki ön koşullara ve ideolojilere yer verilmemektedir. Hegemon konumda olanın karakteristik özellikleri ve kültürel değerleri sistemci yaklaşım bakımından öne çıkan unsurlar değildir. Kültürel değerler yerel unsurlar olarak görüldüğünden uluslararası meseleleri etkilemediği savunulurken günümüzde yürütülen kültürel diplomasi akışı ve etkisine bakıldığında bu açıdan eleştiriye açık kalmaktadır. Diğer yandan Amerikan kültürünün ve diğer kültürlerin hegemonya açısından önemli bir araç olarak kullanılmaya çalışılması ve kamu diplomasisi-yumuşak güç gibi yapıcı unsurlar ile döngünün uzatılmaya çalışılması, döngü kırıcı hegemonya tartışmalarını gün yüzüne çıkarmıştır. Bu faktörler de döngünün sonsuza dek uzatılmamasına rağmen etkilenebildiği anlamina gelebilir.

Dünya sistemleri yaklaşımında sosyal bilimlerin bütüncül bir alan olarak incelenmesi gerektiği savunulmaktadır. Bundan dolayı kültürel değerlerin sosyal bilimleri incelemesini yapmak yerine, sistemin nasıl yapısını incelemek gerekmektedir. Uluslararası sistem içerisinde manevi değerler ve kültür, dünya sistemci yaklaşıma göre yerel unsurlardır. Ancak devletlerin iç çatışmaları, artık teknolojik erişim imkânı ile yayılma hızında önemli bir etkiye sahiptir. Örneğin, Arap Baharındaki yerel sorunların küresel ölçeğe taşınması uluslararası ilişkiler adına oldukça etkili olmuştur. Yada, devletler arası kültürel çatışmalar uluslararası meseleler neden olmaktadır. Kültürel değerler önemli bir etken olduğundan devletler dış politikalarında kültürü empoze etmeye çalışmaktadır. Hatta Nye'ın 
çalışmalarına göre göç akışının artması o kadar olumsuz bir durum olarak ele alınmamalıdır. Çünkü, toplumun göç ettiği ülkeye empoze olma süreci çok kısalmıştır. Böylelikle kültürel farklılıklar sorun olmaktan çıkmakta ve göç, farklı yaratıcı fikirlerin ülkeler arasında hareket etmesine sebep olan bir avantaj olarak değerlendirilmektedir (Nye, 2016: 76-77). Bu da teknolojik çağın bilgi toplumundaki rekabette bir üstünlük konusu olabilmektedir. Yani kültür, bir inceleme alanıdır ve avantaja çevrilebilir.

\section{HEGEMONYA YAKLAŞIMLARINDA GÜÇ OLGUSUNA BAKIŞ}

Hegemonya kavramının farklı teorik görüşler üzerinden tek tek ele alınmasında ortaya çıkan sonuç hegemonyanın oluşumunda ve sürdürülmesinde farklı araçlara öncelik vermesi ve ortak iki noktada tüm görüşlerin birleştiğidir. Bu ortak sonuçlardan ilki, hegemonyanın bir düzen- istikrar temelinde incelendiği; ikincisi ise, güç olgusunun en büyük inceleme alanı olduğudur. Bu bakımdan güç olgusunun her bir kuram tarafından nasıl yorumlandığına değinmek görüşlerin farklılıklarının anlaşılması adına gerekli olmaktadır.

Hegemonik istikrar görüşüne göre güç, klasik anlamdaki askeri ve siyasi tahakküm yetisidir. Bu bakımdan güvenlik odaklı yaklaşımda hegemon konumda olan ekonomik işleyişi koordine edecek ve kriz dönemlerinde istikrarı ekonomik kapasitesi ile idare edebilecektir. Dolayısıyla güç, askeri ve ekonomik kaynaktan sağlanan siyasi karar alma yetisidir.

Liberal kurumsalcı yaklaşıma göre güç olgusu, ekonomik ve askeri kapasitelerin de varlığ ile birlikte diğer aktörleri ikna edebilme ve dağılmış bir kazanç organize edebilme yetisidir. Uluslararası meseleleri büyük yıkımlara sebebiyet vermeden işbirliği ve müzakere süreci ile sonuca bağlayabilme kapasitesi, öncünün alması gereken bir sorumluluktur. Bu bakımdan uluslararası organizasyonları yönlendirebilmek ve diğer aktörleri işbirliğine sevk edebilmek bir güç olarak öne çıkmaktadır. Bunlara ek olarak, diğer aktörleri seçimlerinde kendi çıkarları etrafında toplayabilme ve etkileyebilme yetisi güç olarak tanımlanmaktadır.

Eleştirel yaklaşıma göre güç, entelektüel ahlakı kullanarak diğer sınıfsal toplulukları ikna edebilme kapasitesine işaret etmektedir. Fikirlerin öne çıktığı bu yaklaşımda, fikirlerin etrafında razı gelinerek bir yapı oluşturma ile kendisine sağladığı meşru alan bir güçtür. Üretim biçiminden kaynaklı bu sınıfların durumlarının bilincinde olacak farkındalığa sevk etme ve onları bir araya getirme kabiliyeti gerekmektedir.

Dünya-sistemleri yaklaşımı, hem Marksist güç yorumlarını hem de klasik manadaki gücü ele alır. Ancak buradaki ayrışma gücün değişkenliğine yöneliktir. Güç, klasik manada ekonomik, askeri ve siyasi etki kapasitesi olabilir. Diğer yandan bu güç her bir döngünün sonunda zayıflayarak el değiştirecektir. Dolayısıyla asıl önemli olan gücün maddi etkenler üzerinde bileşenleri bakımından 
elde bulundurulması durumudur. Güç, belli bir süreçteki sermaye birikimi ve siyasi birikim ile ortaya çıkmaktadır. Tüm bu farklılıkların neticesinde hegemonya oluşumunda güç temel ön koşuldur ve düzen yaratma amacı hegemonyal sistemin uluslararası aktörler tarafından kabulünü kolaylaştıran en etkili savunmadır. İstikrar için gücün elde edilme biçimi ve anlamı farklılaşmaktadır.

\section{SONUÇ}

Hegemonya kavramı bir teori değildir. Kavramsal incelemelerde, hegemonyaya farklı savlar üzerinden incelemeler yapılırken onun uluslararası ilişkiler sisteminde tüm etkenleri içine alması gerekmektedir. Çünkü kavram, dünya devletlerarası ilişkiler tarihinde üstün konumda olan ve tahakküm gücünü elinde barındıran aktöre yüklenen bir atıftır ve uluslararası ilişkiler literatüründe bu tahakküm gücüne hegemonya adı verilmiştir. Ancak bu kavramsal analiz tek bir kuram üzerinden değerlendirilemeyecek kadar karmaşık ve kapsamlıdır. Yani hegemonya yaklaşımları tek başına uluslararası ilişkileri yorumlayamayacak durumdayken konu veya süreç bakımından birbirlerinin antidotu olarak kullanılabilen dış politik yaklaşımlar olarak değerlendirilmelidir. Tüm farklı hegemonyaya dair analizlerde ortak nokta ise gücü ele almaları ve düzen-istikrar analizidir.

Hegemonya yaklaşımlarından güç olgusu kavramsal olarak entelektüel bir algı yaratılarak yumuşatılmaya çalışılmıştır. Günümüz anlayışından modern gelişmelerle birlikte hegemonya anlayışının yapısal bir dönüşüme girdiği görülmektedir. $\mathrm{Bu}$ durumda teknolojik çağımızda hegemonyanın varlığı sorgulanırken bunun sadece yapısal bir dönüşümle ve aktör çeşitlenmesi ile revize edildiği söylenebilir. Güç kavramına yeni araçlar eklenerek hegemonik rekabetin devam edeceği söylenebilir.

Yaşanan gelişmeler ve uluslararası ilişkiler yapısındaki araçsal faktörlerin çeşitlenmesi, aktör kavramının değişmesi ve devletdışı aktörlerin bu sistematik yapıda giderek etkili olmasına ek olarak, bireylerin uluslararası politik sürece katılımları da artmıştır. Uluslararası ilişkilerde hegemonya kavramını dönemsel olarak, konu olarak, olay olarak ve yapı olarak farklı yaklaşımlarla ele almak ayrı ayrı mümkündür. Sonuç olarak, hegemonyal analizler üzerinden tek bir görüş ile istikrarlı bir uluslararası ilişkiler sistem önerisi sunmak olanaksızdır. Her bir kuramın hegemonik analizlerinin eksiklerini bir diğer kuram karşılamaktadır. 


\section{KAYNAKÇA}

Alonso, A. M. (1994). The politics of space, time and substance: state formation, nationalism, and ethnicity, Annual Review, Anthropol, (23), 379-405.

Amnesty international (UAÖ) (2020).10 Mayıs 2020 tarihinde https://www.amnesty.org/en/who-weare/ sayfasından erişilmiştir.

Anderson, P. (1998) Gramsci: hegemonya doğu/batı sorunu ve stratejisi (T. Günersel çev.)İstanbul: Alan Yayınları.

Angell, N. (1911). The great illusion: study of relations of military power in nations to their economic and social advantage. Toronto: Mc Lelland and goodchild Publishers.

Baldwin, R. E. (1993). Adapting the gatt to a more regionalized world: a political economy perspective. K. Anderson and R. Blackhurst (Ed.), Regional integration and the global trading system, New York: St. Martin's Press.

Barschdorff, P. (2001). Facilitating transatlantic cooperation after the cold war: an acquis atlantique. Verlag Münster: LIT.

Bieler, A. \& A. D. (2004). A critical theory route to hegemony: world order and historical change: neo-Gramscian perspectives in international relations. Capital and Class, Say1: 28(1), (85113).

Bob Jessop, B. (2005). Hegemonya, post-fordizm ve küreselleşme ekseninde kapitalist devlet. İstanbul: İletişim Yayınları

Byers, M. \& Nolte, G. (Ed.) (2003). United States hegemony and the foundations of international law, Cambridge: Cambridge University Press.

Carr, E. H. (1946). The twenty years crisis, 1919-1939: an introduction to the study of international relations (2. Bask1) Londra: MacMillan \& Co. Ltd.

Copeland, D. C. (2012). Realist perspective: realism and neorealism in study of regional conflict. T. V. Paul (Ed.), International Relations Theory and Regional Transformation içinde (50). Cambridge University Press.

Cox, R. W. (1983). Gramsci, hegemony and international relationas: an essay in method. Millennium - Journal of International Studies, (12), 162-175.

Cox, R. W. (1987). Production, power and world order: social forces in the making of history. Newyork: Coumbia University Press.

Cox, R. W. (1993). Gramsci, hegemony and international relations: An essay in method. Stephen Gill (Ed.), Gramsci, Historical Materialism and International Relations içinde. Cambridge: Cambridge University Press. 
Çelik, Ü. (2013). Soğuk Savaş’tan Libya operasyonu'na NATO - Avrupa Birliği ilişkileri, History Studies, 5 (5), 63-92.

Eichengreen, B. (1987). Hegemonic Stability theories of the international monetary system, Cambridge: National Bureau Of Economic Research.

Eralp, A. (2005). Hegemonya devlet ve ötesi: uluslararası ilişkilerde temel kavramlar. İstanbul: İletişim Yayınları.

European Union Committee Further Enlargement Report. (2006). The Further Enlargement of the EU: threat or opportunity? Evidence given to the House of Lords EU Select Committe, 53rd Report of Session 2005-06, London

Foreign Affairs National Archives (2017). Records of the United States Information Agency (RG 306), 10 May1s 2020 tarihinde https://www.archives.gov/research/foreign-policy/relatedrecords/rg-306 sayfasından erişilmiştir.

Frank, A. G. \& Gills, B. K. (1993). The 5000- year world system: an interdisciplinary introduction, A. G. Frank \& B. K. Gills (Eds.), The World System, Five Hundred Years or Five Thousand? İçinde (3-6). NewYork and London: Routledge.

Gilpin, R. (1988). The theory of hegemonic war: the origin and prevention of major wars. The Journal of Interdisciplinary History/ The MIT Press, 18( 4 (Spring), 591-613.

Gilpin, R. (2001). Global political economy. New Jersey: Princeton University Press.

Gilpin, R. (2007). Küreselleşme, medeniyetler ve dünya düzeni. (G.İ. Çev.) Kara, Divan Disiplinlerarası Çalışmalar Dergisi, ( 23)21-37.

Gramsci, A. (1989). Hapishane defterleri. (K. Somer, Çev.) İstanbul: Onur Yayınları.

Gramsci, A. (1997). Hapishane defterleri. (A. Cemgil, Çev.) İstanbul: Belge Yayınları.

Griffiths, M. (2011). Fifty key thinkers in international relations (uluslararası ilişkilerde temel düşünürler ve teoriler). ( Cesran, Çev.)Ankara: Nobel Yayınevi.

Guzzini, S. (2006). "From (alleged) unipolarity to the decline of multilateralism? A power-theoretical critique. E. Newman, R. Thakur ve J. Tirman (Ed.), multilateralism under challenge? power, International order, and Structural Change içinde 125 India: United Nations University Press. Hayden, C. (2012). The rhetoric of soft power: public diplomacy in global contexts. New York: Lexington Books.

Ikenberry, G. J. (2001). After victory: institutions, strategic restraint, and the rebuilding of order after major wars. Princeton ve Oxford: Princeton University Press.

Jain, R. K. (1996). Hierarchy, hegemony and dominance: politics of ethnicity in Uttar Pradesh, Economic and Political Weekly, 31 (4) , 215-223

Johnson, T. \& Heiss, A. (2018). Liberal institutionalism. (İkinci Bask1). T. G. Weiss \& R. Wilkinson (Ed.), International Organization and Global Governance. London: Routledge. 
Kennedy, P. M. (2001) Büyük güçlerin yükseliş ve çöküşleri: 16. Yüzyıldan günümüze ekonomik değişim ve askeri çatışmalar (B. Karanakçı, Çev.). İstanbul: Türkiye İş Bankası.

Keohane, R. \& Nye, J. (1987). Power and interdependence. International Organization/ The MIT Press 41( 4), Güz, 725-753.

Keohane, R. (1984). After hegemony: cooperation and discord in the world political economy. Princeton: Princeton University Press.

Keohane, R. (1988). International institutions: two approaches. International Studies Quarterly, 32(4), 382-393.

Kindleberger, C. (1973). The World in depression: 1929-39 Chapter 14. Berkely: University of California Press.

Kindleberger, C. P. (1986). International public goods without international government, The American Economic Review, 76(1), 1-13.

Köksoy, E. (2014). Kamu diplomasisi ve halkla ilişkiler ilişkisi: Kuramsal bir değerlendirme. Marmara İletişim Dergisi / Marmara Journal of Communication, 22 (211-231) .

Krasner, S. D. (1982). Structural causes and regime consequences: regimes as intervening variables. International Organization, 36(2),185-205.

Krasner, S. D. (1983). Internatioal regimes. Ithaca and London: Cornell University Press.2

Lentner, H. H. (2006). Hegemony and power in international politic M. Haugaard \& H. H. Lentner (Eds.), Hegemony and power: consensus and coercion in contemporary politics içinde (p.90). Oxford: Lexington Books.

Louati, C. (2011). Military Intervention In Libya: Where Is ESDP? 10 Mayıs 2020 tarihinde http://www.nouvelle-europe.eu/en/military-intervention-libya-where-esdp sayfasindan erişilmiştir.

Melissen, J. (2005). The new public diplomacy: between theory and practice. J. Melissen (Ed. ), The public diplomacy: soft power in international relations içinde (3-4). Newyork: Palgrave MacMillan.

Modelski, G. (2005). Küresel politikanın uzun döngüsü ve ulus-devlet. Uluslararası İlişkiler, 2 ( 7) (Güz), 3-30.

Morton, A. D. (2011). Gramsci'yi çözümlemek: küresel politik iktisatta hegemonya ve pasif devri. (B. Baysal, Çev.) İstanbul: Kalkedon Yayınları.

Mundell, R. M. (1989). International Monetary Options. Cato Journal, 3(1) (spring) 189.

Norrlof, C. (2010). America's global advantage: us hegemony and international cooperation. Cambridge: Cambridge University Press.

Nye, J. (2016). Amerikan yüzyılı bitti mi? İstanbul: Röle akademik yayıncılık.

Nye, J. S. (1990). Soft power, Foreign Policy, (Nu. 80), Güz, 153-171. 
Nye, J. S. (2002). The Paradox of American power: Why the world's only superpower can't go it alone. Oxford: Oxford University Press.

Nye, J. S. (2004). The decline of America's soft power - Why Washington should worry. Foreign Affairs, $16 / 83$.

Nye, J. S. (2005). Yumuşak Güç. ( R. İ. Aydın Çev.). Ankara: Elips Kitap.

Nye, J. S. (2009). Get smart: combing hard and soft power. Foreign Affairs, 88( 4) (July/August), 160-163.

Nye, J. S. (2015). Amerikan yüzyılı bitt mi? (B.Beşgül Çev.). İstanbul: Uluslararası İlişkiler Kütüphanesi.

Nye, J. S. \& Keohane, R. (1971). Transnational relations and world politics. International Organization, 25(3), Yaz, 329-349.

Olson, M. (1986). A theory of the incentives facing political organizations: neo-corporatism and the hegemonic state. International Political Science Review, (7), 165-89.

Potyemkin, V., Baruşin, S., Efimov, A., Mintz, İ. \& Kosminski, E. (2002) vd., Uluslararası ilişkiler tarihi: diplomasi tarihi Cilt I (2. Basım). ( A. Tokatlı, Çev.) İstanbul: Evrensel Basım Yayın.

Power, P. (1981). Amnesty international: The human rights story. Oxford: Pergamon Press.

Rhodes, P.J. (2019). Antik Yunan'in kisa tarihi (A short history of the Ancient Greece). ( C. Atay, Çev.) İstanbul: İletişim Yayınları.

Robinson, I. W. (1998). Promoting polyarchy: globalization US intervention and hegemony. Cambridge: Cambridge University Press.

Robinson, J. (1983). Reification and Hegemony: The Politics Of Culture in The Writings of Georg Lukács and Antonio Gramsci 1918-1938, McClill University, Department of History, (A thesis submitted to the Faculty of Graduate for the degree of the Doctor of Philosoph). Montréal.

Ruggie, J. G. (1982). International regimes, transactions, and change: embedded liberalism in the postwar economic order, International Organization, 36( 2), (Spring), 379-415.

Ruggie, J. G. (1975). Intemationail responses to technology: concepts and trends. International Organization, (29) (Summer), 559.

Salmon, T. C. (2004). United in its diversity(or disunited in adversity) : that is the question for the EU and THEESDP, Perspectives on European Politics and Society, 5 ( 3), 447-468.

Sinclair, T.J. ( 1996). Beyond international relations theory: Robert Cox and appreaches to world order. R.W. Cox \& Timothy J. Sinclair (Eds.) Approaches to the world order. Cambridge: Cambridge University Press,

Snidal, D. (1985). The limits of stability theory, International Organization, 39 (4), Autumn, 581.

Stephan H. and Simmons, B. A. (1987). Theories of international regimes. International organization 41( 3), 491-517. 
Türk Dil Kurumu (2019) Hegemonya, $10 \quad$ May1s 2020 tarihinde http://www.tdk.gov.tr/index.php?option=comgts\&kelime=HEGEMONYA sayfasindan erişilmiştir.

Uça Güneş, E. P. (2016). Toplumsal değişim, teknoloji ve eğitim ilişkisinde sosyal ağların yeri, AU (Anadolu Üniversitesi) Açıköğretim Uygulamaları ve Araştırmaları Dergisi (AUAd), 2 ( 2), 191-206.

Wallerstein, I. (1995). After liberalism, New York: The New Press.

Wallerstein, I. (1997). The Capitalist world-economy. Cambridge: Cambridge University Press.

Wallerstein, I. (1999). The End of the world as we know it: social science for the twenty-first century, Minneapolis London: University of Minnesota Press.

Wallerstein, I. (2003). Historical capitalizm with capitalist civilization, New York: Verso..

Wallerstein, I. (2004). World-systems analysis: An introduction, the USA: Duke University Press.

Wallerstein, I. (2011). The Modern world-system I, capitalist agriculture and the origins of the european world- economy in the sixteenth century. Berkeley: University of California Press.

Weber, M. (1978): Economy and society: an outline of interpretive sociology (second vol). G. Roth \& C. Wittich (Ed.). Berkeley: University of California Press. 